\title{
一原報一
}

\section{佐伯勝太郎博士の方法による支那蘆 蒸解廢液より曹達回收に關する研究}

\author{
藤 井 光 雄 \\ (束京帝國大學軈用化學科瀻維素研究室)
}

\section{緒言}

支那离蘆の曹達法蒸解に依り生ずる曹達廢液よ

り北性曹達回收て關する小政究を報告せんとする

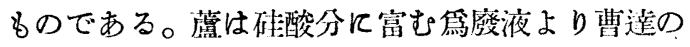
回收を困難ならしむる。贸ち膠狀の硅酸つ沈澱が 湦性化工程の障碍となる。本砾究は此の廢液中の 砋酸分除去法として黑灰を作る際石灰を添扣し 䂜酸石灰として沈澱除去せしめんとするものであ る。此の方法は管て印刷局抄紙部て於て佐伯勝太 郎博士の考案せる方法であつて、稻橖に就て行は れたものである。本研究の目的は同博士の法を 蘆に䢛用し、其つ可否站びに經濟上の見地より工 紫化の適否を論ぜんとするものである。而して其 の概略を和らんとして豫備的實驗を行ひたれば茲 に報告せんとするものであるが、短時日間に行ひ をるものなれば、敬めて不得要領なる事は著者も 認むる所なれぼ、以下其の骨子を略記して參考に 資せんとする。

\section{原料}

支邦揚子汒应蘆を原料とする。蘆は袷を除を曹

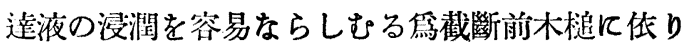
節を碎を、襤褸截斷機を使用して本均 5-10 粧
に截斷した。藘の工業分析結果は次の如くであ る。

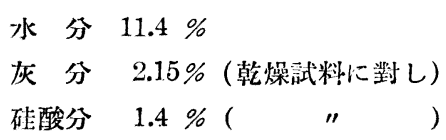

\section{實驗方法操作及び裝置}

惯驗は二回行へるも最初の實驗は主として設備 の不充分職工の不熱練完成直後の燒成嘘を使用せ る䉆等と荐へられる諸原因に依り、甚だ收量惡し き結果を得をる䉆に、玆には主に第二回實驗に就 て述べんとする。

\section{蒸解法及び蒸解罐}

蒸解罐は徑 5 吹の球形鐵製蒸解罐を用ひた。回 轉數は一分間に約 $11 / 4$ 回轉であつた、や」速過ぎる と考へたが調篩不可能であつた。各原料の混合割 合は蘆に對し20\%の街性曹達を約 $8 \%$ 水溶液とし て添加した。郎ち第一回實驗に於ては舊 150 互に 對し荇性曹達 30 正を水 360 立に溶解して添加し、 第二回實驗に於ては蘆 200 正?亿對 し菏性曹達 40 量を水 490 立に溶し添加した。以上の割合にて釜 詰めを行ひ、蒸解に附する前に 1 時間空轉せしめ た。之は蒸解液の蘆中に均等に分布せしめんが爲 である。1 時間後蒸氣を迕り 12 時間蒸解を行つ 


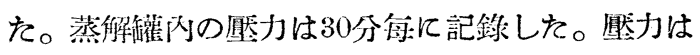
大體 $70 \mathrm{lbs} / a^{\prime \prime}$ 前後で他方に於ける蒸氣使用量に 應じ最高 80 封度最低 55 封度の變化があつた。第 二回試驗に於ても殆んで同樣で最高75封度最低 60 封度を示した。12 時間後に蒸解を終り、人孔に金 網を張り孔を下うに向け、本製容器に廢液を流出 せしめた。廢液は濃褐色を呈してるる。廢液の流 出が僅少になつた時、水 180 辛を加へ蒸氣を揆り、 1 時間回轉し、洗滌を行ふ。洗桬は 2 回行つた。

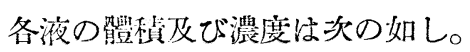

\begin{tabular}{|c|c|c|}
\hline 籘一回試驗 & 濃 莸 & 齬. 積 \\
\hline 廢 液 & Bé 11. & 約 288 立 \\
\hline 第一回洗滌液 & 7 & 276 \\
\hline 符二回 " & 4 & 84 \\
\hline 混 合 液 & 8 & 648 \\
\hline \multicolumn{3}{|l|}{ 籍二回試驗 } \\
\hline 履 液 & 8 & 516 \\
\hline 第一回洗涤液 & 5.5 & 264 \\
\hline 第二回 " & 1.5 & 144 \\
\hline
\end{tabular}

（各液量の相異は 流出せしめる時間飞䨘驗時間 の關係上長䙵があつた篇である)

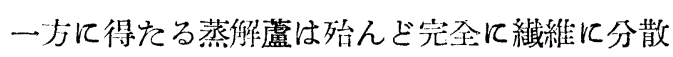
し小量づつ総くるつれて小粒となつてわた。從て 抄紙するに當つて吒解の必要を認めざる程度であ る。エスパルト纎維に極めてよく類似し、長さ短 く且圆形の細胞の含有率が多レ。從て製紙試驗の

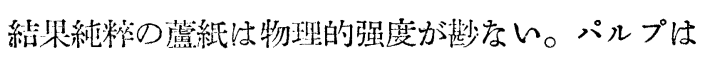
漂白が容易であつた。

以上の如くして得たる廢液を加熱濃縮し石灰を 混じて燒成し、一方に炭酸曹達を得、他方に硅酸 曹達を硅酸石灰及び炭酸曹達に變化せしめんとす
るのである。

\section{燒成爐}

廢液の燒成は特に設計築造せる爐を用ひた。爐 は上下二段沉分ち、下段は反射爐とし、上段は 100 $\times 75$ 平方糎、下段は $75 \times 75$ 平方粝で、焚口は下段 の一端に在り、火焻が水平に流れて下段の他端に 至り、其處より上方に显り、文水平に上段燒成空を 通過し煙道に出る。上段燒成空の天井は鐵製蒸發 鍋の底とし、餘熱を利用し廢液を濃縮せんとする。 鍋の大きさは縱 135 糎幅 75 糎深 20 粝でする。本 嘘の使用方法としては先づ塺液を上部の蒸發鍋に 入れ、之れを煮詰め、上段燒成空に落し、次で下 段燒成堂に於て石灰を混入し燒成せんとするもの である。されど實際には此の方法にては、蒸發能 率惡るく、燃料及び時間の不經濟なりし雼め、他 所に大なる蒸發鍋を設け、此處に於て Bé $25^{\circ}$ 又

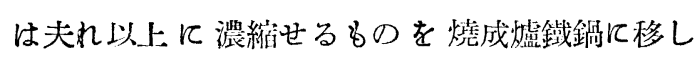
た。從て此處に於ては殆んぼ蒸發の必要なきやう にし、Bé $25 \sim 30^{\circ}$ の濃縮㾱液を少量づつ上段燒成 室を通過せしめ、下段燒成空に落し、濃重なる廢 液に石灰を立分よく混和し、適當量下段に溜りた る時、火力を强め、充分なる擤排を行ひつ」乾燥 燒成した。

廢液と石灰混和物は乾燥すれば自己然燒を起 す。此の自己燒燃終了せるるのは、黑色塊狀の物 質である。從て更に燃料に依り、未燃燒有機物を 燃燒せしむるを姴する。此の時の火力師ち溫度は 、研究を要するものと考へる。火力弱を時は充分に 燒くを得す、、火力强をに過る時は熔融し硬き結塊 
を作る。や」表面の熔融する程度に火力を保ち、 充分良く攪找し結塊するを防ぎ、常に細粒に保ち、 均一に燒成し、時々一部取出し灰白色乃至暗灰色 となり、內部に黑班を認めざるに至りて燒成を止 さ。燒塊は㩭挥を立分ならしむる事に依り可なり 細く仕上げ得る。㨨汼はボイラー用灰搔を用ひ た。色調は石灰の添加量に依り異る。最適添加量

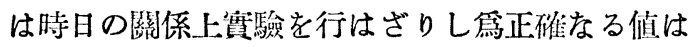
不明なるる、回收し得られる炭酸曹達の重量以下 の消石灰量で充分なる事は明である。消石灰量多 き程燒成は容易であるが、最少量は未詳なれミ゙、可 なり僅少にても其の目的を達し得らるつものと考 一る。又燒塊も石灰量齿少〈且焙燒不充分にして色 調の㖣黑出のものb、望性化後の上澄液は清澄透 明であつた。從て石灰と砫酸分との反應恃黑灰の 自己然燒終了直後に於ては、既に完結せるもと荐 ヘらる。

以上の如くして得をる燒塊は溶解を速める爲に 粉磪した。時及蒸氣を吹を込み熱湯に保ち、充分 溶解せりと認めてる時、此の液を菏性化する。苛 性化の時加へる石灰量は炭酸曹達量（液の比重よ り算出した)江對し生石灰として100\%になる樣に 消石灰を加へた。棐性化反應は可逆反應をれば、 液の濃度は稀蒖なる程息く、Bé $11^{\circ}$ 程度とするが 最も好都合である。第一回試驗に於ては容器の關 係上止むを得和Bé $13^{\circ}$ に溶解した。第二回試驗に

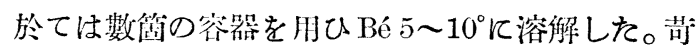
性化は良く㨨汼しつ」蒸氣を 30〜50 分間通じ、 更に 2 時間程攪拌を續行する事に依り完結する。
苛性化終りたるものは放置すれば沈澱物は速に 沈澱し、上澄液は清澄透明なる淡黄色である。郎 ち硅酸分除去の目的を完全に達した理である。 得たる液量站に比重其の他より苛性曹達回收率 を計算するに、第一回試驗に於ては $37 \%$ 、第二 回試驗に於ては $65 \%$ であつた。

\section{實驗結果に對する考察}

第一回試驗に於ける收量の甚だ尠をは職工不熟 練の爲の失敗以外の主をる原因として、大體次の 如きものが考へられる。(1) 使用爐の築造の餘り 簡單なりし䍃充分注意せるにも係らず、使用中多 數の龜裂を生じ、廢液の漏洩を來した。（2）新爐 なる故に爐內一燒き着く量端に浸大する量相當多 し。（3）蘆パルプに含有せらるつるの。第二回試 驗に對しても同栐なる損失の原因を擧げ得へし、 されど職工の熟練の增加、新爐に基因する損失の 減少等に依り、回收率の增大を來してるる。完全 なる爐を用ゆる事及び實驗回數を增加する事に依 り、 $80 \%$ 附近の回收率を得るは容易なる事之確信 するるのでする。更に燒成の際添加する石灰とし て消石灰を用ひたれど、葑性化工程に於けて得ら るつ石灰泥を使用すれば、石灰に就ては特に意を 用ゆる必要なく、且石灰泥中に含有せらる〉荝性 曹達をも回收し得らる。從て本法を貫施するに當 り（1）蒸解蘆の洗滌度を決定し（2）廢液燒成吉連 續的に行ひ、（3）燒成度の決定、攪俳の經濟的； 法を考虑する事に依り、相等有利に曹達回收を行 ひ得るものと考へる。

\section{使用燃料に就て}


本法の工業化を右右する最大の要素は燃料使用

量である。本研究に於ては小規模の爐を使用し且 つ不連續的に燒成を行ひたるを以て莫大の石炭を 消費した。郎ち每朝點火し爐が熱し完全に作業し 得るに至るまでに約四時間を要し此の間に使用す る石炭の大部分は爐の加熱飞消費せらるつ。第二 回試驗江於て使用せし石炭 (撫順粉炭) 量は 230 瓦であつた、而して本爐に於ても書夜續行する事 に依り石炭使用量を激減し得るものと考へる。

\section{總括}

（1）支那蘆の曹達法蒸解廢液上り苛性曹達回收 法として石灰を添加し硅酸分を除去する方法を研
笑した。

（2）實驗結果及び操菜妝態より将察し爐の改 良、燒成度の決定站に連續的に操蒋する事に依り 回收率 $80 \%$ 附近を相當有利に回收し得らるつも のであることを推論した。

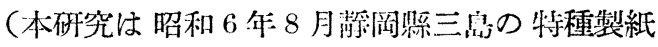
株式會社に於て行ひたるるので、䨘驗上に各種の 御便宜をま計り下されし厚小㸚授、御懇切なる御 指導を賜りし佐伯博士、終始實驗を御援助下され し伎伯鿆二氏站に同社の技師其他の諸氏に深く感 謝の意を表する。)

(昭利 6 年 11 月 21 日受理)

人絹細絲の光線の屈折市場に於ける各種類の人造絹絲の比複屈折 (Spezifische Doppelbrechung）は著るしき區別がある。著者は此の各種の人絙の複屈折を研究し次の 結論を得た。(1)市場の人組細絲は同一製法の太い絲上りも常に强き複屈折をなす。(2)細

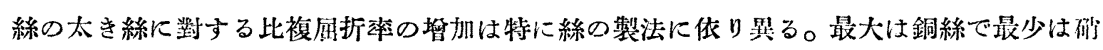
酸絲である。（3)供試せられたる細絲の比複屈折率は硆酸絲は +0.042 以上でヴィスュー ス絲は +0.036, 銅絲は +0.032の順になる。同柡な順列は太い絲にも觀察される。(4)細 絲の主属折率は絲を偏光面に對して本行及び直角に置いた場合に、前者の時少なく後者は 大きい、太い絲の場合も同栐である。(5)中間の属折㕠に關しては細絲と太い絲の間に何 等云ふ可き區別がない。

人造絹絲の强き複属折は製造の際の伸張作用若しくは之れと一緒に起る强き有方州の分 子若しくは分子團の本行配列に歸せられる。

( Prof. Dr. A. Herzog, Kunst-Seide 1, 6, 1931) （藤刜) 


\title{
CELLULOSE INDUSTRY \\ THE JOURNAL OF THE CELLULOSE INSTITUTE, TOKYO, JAPAN \\ VOL. 7 December, 1931, No. 12
}

\author{
ABSTRACTS FROM THE TRANSACTIONS \\ RECOVERY OF SODA FROM THE WASTE LIQUOR OBTAINED \\ FROM DIGESTION OF CHINESE REEDS.
}

\author{
By Mitsuo FUJII \\ (Received Nov., 21, 1931)
}

When cellulosic materials contain silicate, the recovery of soda in the soda digestion is very difficult. In this report, the regeneration of the soda from cooked liquor of the reeds was studied. The method was investigated by Dr. Katsutarō Saeki and applied to the case of rice stalk with good results. The principle of the method is as follows; the silicate changes to sodium silicate by digestion with soda, and the black ash, containing sodium silicate, is calcined with lime, (for this purpose, lime-mud, product of causticisation of soda ash, can be used), sodium silicate being converted to calcium silicate and sodium carbonate. As the calcium silicate is insoluble in water and easily precipitated, after the causticisation of recovered sodium carbonate very clear and transparent solution of sodium hydroxide is obtained.

The Chinese reeds were crushed and cut to $5-10 \mathrm{~cm}$. long.

The analysis of the reeds was;
Moisture
$11.4 \%$
Ash (on dry base)
$2.15 \%$
Silicates (on dry base) $1.4 \%$

The raw material was put into a spherical digester, and digested with $20 \%$ of sodium hydroxide ( $8 \%$ solution) in weight against reeds. The steam pressure was $75 \mathrm{lbs}$. per. sq. in. on average, and the time of digestion was 12 hours. Then the waste liquor was drained, and the pulp was washed with water, and all liquors were evaporated and calcined.

\section{EVAPORATOR AND RECOVERY FURNACE.}

Reverberatory furnace, specially constructed for this purpose, was used. It has two compartments (upper and lower), and an evaporator was placed as the cover of the furnace. In the evaporator and the upper compartment, the waste liquor was evaporated and concentrated to 25-30 Bé and then droped to lower compartment. In the lower compartment, it was mixed with lime, and dried, burned, and 
(60)

calcined. The calcination was carried out under frequent stirring and careful regulation of temperature, and completed when the ashes became dark white. After the causticisation of these ashes (mainly consisted of .soda ash, calcium silicate, and lime), very clear and pale yellow solution of sodium hydroxide was obtained.

\section{RESULTS AND DISCUSSION.}

In the first experiment, $37 \%$ of initial sodium hydroxide was recovered, and in the second experiment, $65 \%$ was recovered.

The chief reasons for these poor results will be attributed to (1) unskilfulness of the workmen, (2) adherence of black ash to the wall of new furnace, (3) leakage of the liquor from the wall (as the furnace was of simple construction many leakages were observed,). If these defects, are put away, if may be casy to recover about $80 \%$ of initial sodium hydroxide and this process can be advantageously applied to paper making. 